\title{
Cuscuta janarthanamii (Convolvulaceae), a new species from lateritic plateaus of Western Ghats, India
}

\author{
Kolte R.R. ${ }^{1 \star}$, Deshpande A.S. ${ }^{1}$, Gaonkar V.U. ${ }^{1}$, Prabhu T.N. ${ }^{1}$ \& S.S. Kambale ${ }^{2}$ \\ 'Department of Botany, Goa University, Taleigao Plateau, Goa - 403 206, India. \\ ²Deptartment of Botany, MVP Samaj's Arts, Commerce \& Science College, Tryambakeshwar, Nashik district, Maharashtra - 422 212, India. \\ *Email: rutuja24kolte@gmail.com
}

\begin{abstract}
Cuscuta janarthanamii (Convolvulaceae) is herein described and illustrated as a new species. This new species is morphologically similar to C. capitata Roxb. and grows parasitically on Lepidagathis keralensis Madhus. \& N.P.Singh (Acanthaceae). A detailed description and the photographs of the new taxon are provided here.
\end{abstract}

Keywords: Goa, Lateritic rock outcrop, Lepidagathis keralensis, Parasitic.

\section{Introduction}

The genus Cuscuta L. (Convolvulaceae) comprises c. 200 species (Mabberley, 2017), distributed worldwide. Yuncker (1932) had grouped all the species of Cuscuta in three subgenera: Cuscuta, Grammica (Lour.) Peter and Monogynella (Des Moul.) Peter. However, Costea et al. (2015) recognized four subgenera: Cuscuta L. subgen. Cuscuta, Grammica (Lour.) Peter, Pachystigma (Engelm.) Baker \& C.H.Wright and Monogynella (Des Moul.) Peter. Thirteen species of the genus are found in India, among which six are present in the Western Ghats (Santapau \& Henry, 1973; Nayar et al., 2014; Udayan et al., 2016). The recently described C. krishnae Udayan \& Robi is endemic to Kerala and belongs to subgenus Monogynella (Udayan et al., 2016). While exploring herbaceous vegetation of lateritic plateaus in Goa, the current Cuscuta species was collected. After examining the specimen and perusal of the literature (Yuncker, 1932; Costea et al., 2015) authors came to the conclusion that it is a new species which is described and illustrated here. The very short or inexistent styles together with the indehiscent or late dehiscent fruits are characters that suggest

Received: 13.8.2018; Revised \& Accepted: 28.09.2019

Published Online: 30.09.2019 that it belongs to subgenus Cuscuta sect. Epistigma Engelm. Among the five species of this section, it shows close resemblance to C. capitata Roxb., which is distributed in the mountains of Central Asian countries and North India. They show similarities in characters such as, fruit dehiscence, persistent corolla in fruit, infrastaminal scales and papillate flowers.

Cuscuta janarthanamii Kolte, A.Deshp. \& Kambale sp. nov.

The species is closely allied to C. capitata Roxb. but differs in pale yellow, tubular tetramerous flowers ( $v s$ red or rose coloured, campanulate, tetramerous or pentamerous flowers); pedicels well developed and up to double the length of flower (vs subsessile or equal the length of flower); calyx half the size of corolla tube ( $v s$ as long as or longer than corolla tube); infrastaminal scales less than half the length of corolla tube, always present ( $v s$ shorter than corolla tube, sometimes apparently absent); ovary globose with very minute style, stigma much longer than style ( $v s$ ovary with rostrum, pyriform, stigma equal to or shorter than rostrum).

Type: INDIA, Goa, North Goa district, Honda, 19.04.2017, Rutuja R. Kolte 801 (holo CAL; iso BSI, SUK, Goa University Herbarium). Figs. 1 \& 2

Parasitic herbs. Stems twining, glabrous, leafless, c. $1 \mathrm{~mm}$ across, pale yellow to purple (or purple tinged), scales c. $1 \mathrm{~mm}$ long. Flowers solitary or 2-4 flowers in a loose glomerule, pedicellate, tetramerous, cylindrical; bracts c. $1 \mathrm{~mm}$ long, at the base of inflorescence, ovate, glabrous, obtuse at apex, hyaline or pale yellow with purple tinge; pedicels $c .1 \mathrm{~cm}$ long, about double the length of the corolla, glabrous, pale yellow. Calyx 4-lobed, $2.5-2.8 \times 0.8-1 \mathrm{~mm}$, half or less than half the 


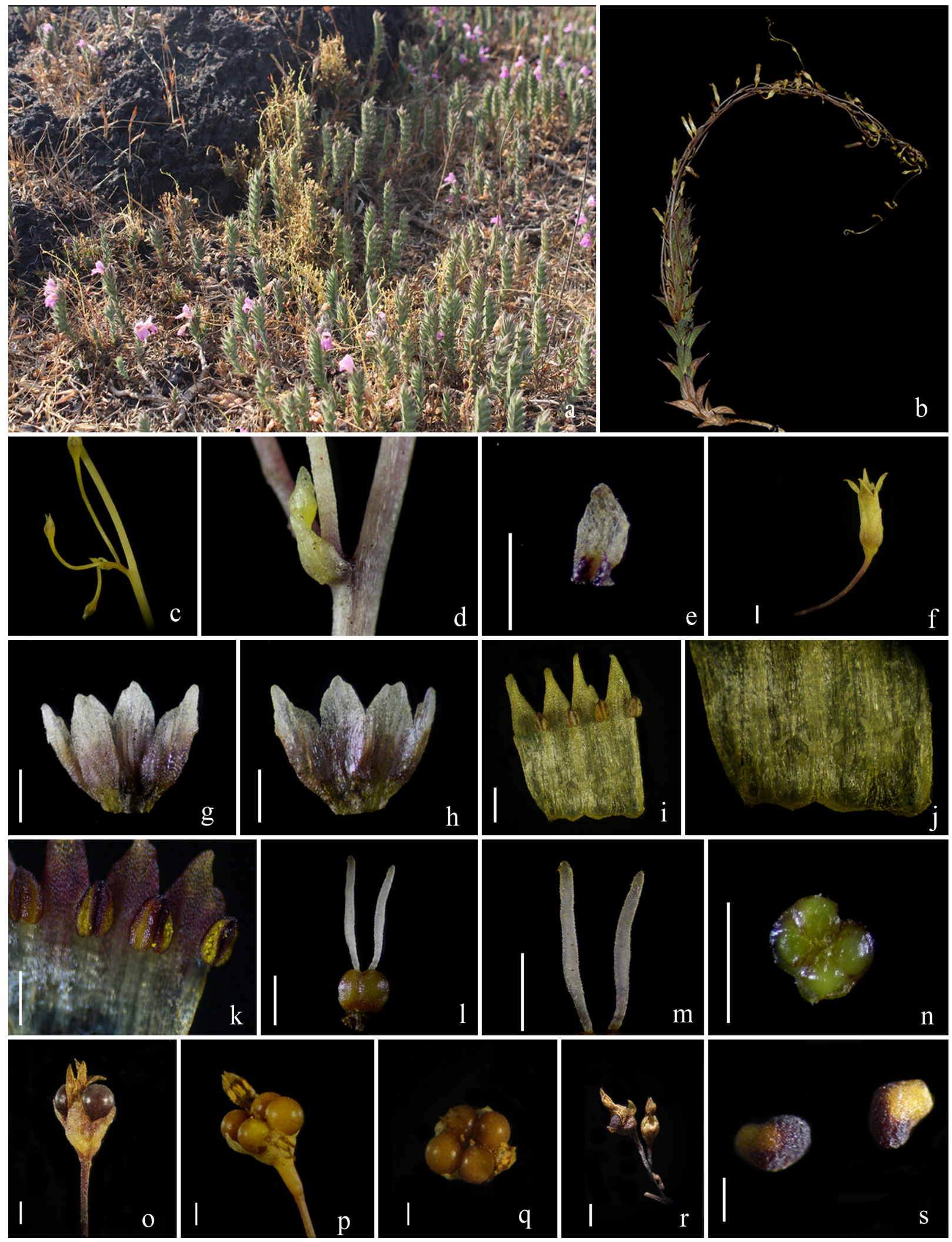

Fig. 1. Cuscuta janarthanamii Kolte, A.Deshp. \& Kambale: a. Habitat; b. Habit; c. Inflorescence; d. Bract attached to inflorescence; e. Bract; f. Flower along with pedicel; g. Calyx-outer surface; h. Calyx-inner surface; i. Corolla-split open; j. Infrastaminal scales; k. Stamens attached to corolla; I. Gynoecium; m. Stigma \& style-close up view; n. Ovary T.S.; 0-r. Diversity in capsules; s. Seeds. (Scales: e-i \& I-s $1 \mathrm{~mm}$; k 0.2 mm) 


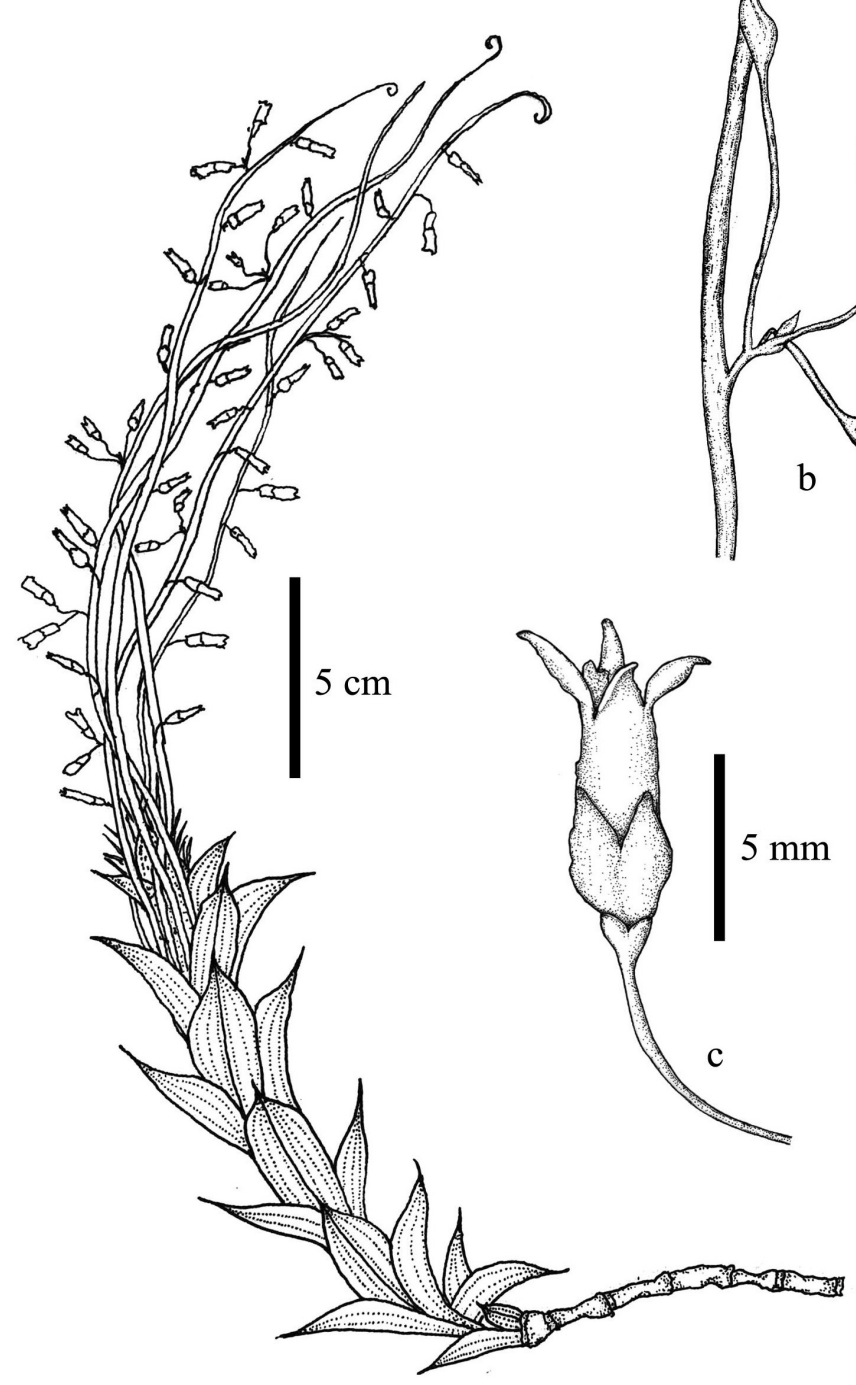

a
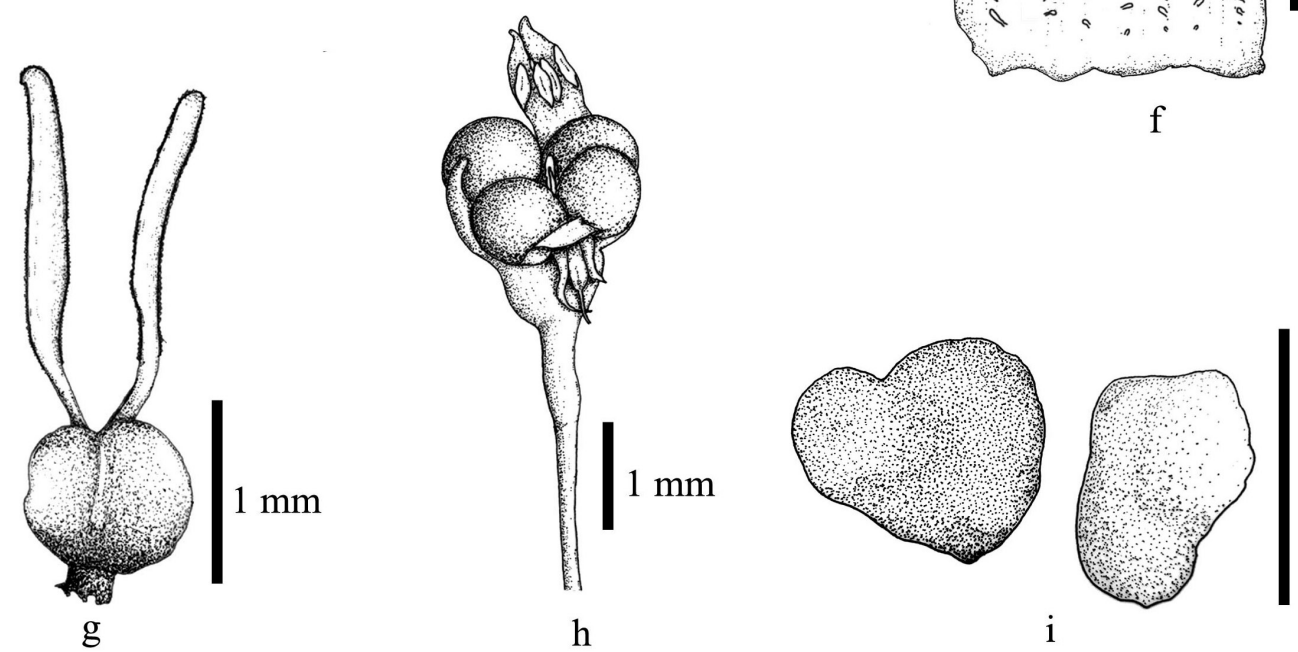

$1 \mathrm{~mm}$

Fig. 2. Cuscuta janarthanamii Kolte, A.Deshp. \& Kambale. a. Habit; b. Inflorescence; c. Flower; d. Bract; e. Calyx; f. Stamens attached to corolla; g. Gynoecium; h. Capsule; i. Seeds. 
length of corolla, campanulate, glabrous, with translucent papillae, persistent; tubes $1.5-1.8 \mathrm{~mm}$ long; lobes c. $1 \mathrm{~mm}$ long, ovate, sub-equal, obtuse at apex, margins irregular. Corolla 4-lobed, 4-4.5 $\times$ c. $1 \mathrm{~mm}$, rotate, papillate, pale yellow; corolla tube 3.5-4 $\mathrm{mm}$ long, fimbriate infrastaminal scales at lower half of tube, alternipetalous; lobes c. 1 $\mathrm{mm}$ long, acute at apex. Stamens 4, epipetalous, alternipetalous; filaments rudimentary or absent; anthers $0.2-0.3 \mathrm{~mm}$ long, brown; pollen grains yellow. Ovary c. $0.75 \mathrm{~mm}$ diam., globose, notched at apex, glabrous; locules 2, with distinct septum, two ovules in each locule; styles 2 (rarely 3 or 4), c. $0.5 \mathrm{~mm}$ long, distinct, white; stigma c. 1.5 $\mathrm{mm}$ long, elongated, papilose, white. Capsules c. $5 \mathrm{~mm}$ across, non-circumscissile, when young covered by corolla, deshisced at maturity through intrastylar openings. Seeds 1 to $4, c .1 .5 \times 1.0 \mathrm{~mm}$, irregularly obovate, glabrous, dark purple, yellow when young, detached at maturity.

Habitat: Cuscuta janarthanamii is found growing on Lepidagathis keralensis, which is found on lateritic plateaus of Maharashtra, Goa and Karnataka. However, this new species of Cuscuta is found only at two localities in Goa.

Distribution: So far known only from two localities in Goa.

Flowering: February - April.

Fruiting: April - June.

Etymology: The specific epithet is admirably given in the honour of Prof. Malapati Kuppuswamy Janarthanam, Department of Botany, Goa University for his contribution in the field of angiosperm taxonomy and conservation of the rare and endemic species of Western Ghats.

Note: The last species described in the subgen. Cuscuta sect. Epistigma was C. haussknechtii Yunck. (Yuncker, 1932). After a long gap this new species has been published from same section. Cuscuta janarthanamii is the only species of subgen. Cuscuta known to be endemic to India. This species grows on the lateritic plateaus from February to June. The host, Lepidagathis keralensis grows profusely on lateritic plateaus and observed to be the dominant taxon in this season. This species was found growing on a single host, which seems to be monocarpic (pers. observation). Hence, the distribution and occurrence of this new species mostly depend upon the extent of the host species.

Additional specimen examined: INDIA, Goa, North Goa district, Honda-Usgao Road, 13.03.2017, Rutuja R. Kolte \& Anup S. Deshpande 1820 (Goa University Herbarium).

\section{Acknowledgements}

RRK is thankful to Rufford Foundation for providing financial support.

\section{Literature cited}

COSTEA M., GARCIA M.A. \& S. STEFANOVIC 2015. A phylogenetically based infrageneric classification of the parasitic plant genus Cuscuta (Dodders, Convolvulaceae). Systematic Botany 40: 269-285.

MABBERLEY D.J. 2017. Mabberley's Plant-Book: A portable dictionary of plants, their classification and uses. Fourth Edition. Cambridge University Press, Cambridge. p. 260.

NAYAR T.S., SIBI M. \& A.R. BEEGAM 2014. Flowering plants of the Western Ghats. Volume 1. Jawaharlal Nehru Tropical Botanical Garden and Research Institute, Thiruvananthapuram. p. 290.

SANTAPAU H. \& A.N. HENRY 1973. A Dictionary of the flowering plants in India. (Repr. 1998). National Institute of Science Communication, New Delhi.

UDAYAN P.S., ROBI A.J., MANUDEV K.M. \& P. SUJANAPAL 2016. Cuscuta krishnae (Convolvulaceae), a new species from southern Western Ghats, Kerala, India. Webbia 71(1): 45-47.

YUNCKER T.G. 1932. The genus Cuscuta. Memoirs of the Torrey Botanical Club 18: 113-331. 